NASA/TM-2004-213183

\title{
Evaluation of High Temperature Knitted Spring Tubes for Structural Seal Applications
}

Shawn C. Taylor

Case Western Reserve University, Cleveland, Ohio

Jeffrey J. DeMange

University of Toledo, Toledo, Ohio

Patrick H. Dunlap, Jr. and Bruce M. Steinetz

Glenn Research Center, Cleveland, Ohio 
Since its founding, NASA has been dedicated to the advancement of aeronautics and space science. The NASA Scientific and Technical Information (STI) Program Office plays a key part in helping NASA maintain this important role.

The NASA STI Program Office is operated by Langley Research Center, the Lead Center for NASA's scientific and technical information. The NASA STI Program Office provides access to the NASA STI Database, the largest collection of aeronautical and space science STI in the world. The Program Office is also NASA's institutional mechanism for disseminating the results of its research and development activities. These results are published by NASA in the NASA STI Report Series, which includes the following report types:

- TECHNICAL PUBLICATION. Reports of completed research or a major significant phase of research that present the results of NASA programs and include extensive data or theoretical analysis. Includes compilations of significant scientific and technical data and information deemed to be of continuing reference value. NASA's counterpart of peerreviewed formal professional papers but has less stringent limitations on manuscript length and extent of graphic presentations.

- TECHNICAL MEMORANDUM. Scientific and technical findings that are preliminary or of specialized interest, e.g., quick release reports, working papers, and bibliographies that contain minimal annotation. Does not contain extensive analysis.

- CONTRACTOR REPORT. Scientific and technical findings by NASA-sponsored contractors and grantees.
- CONFERENCE PUBLICATION. Collected papers from scientific and technical conferences, symposia, seminars, or other meetings sponsored or cosponsored by NASA.

- SPECIAL PUBLICATION. Scientific, technical, or historical information from NASA programs, projects, and missions, often concerned with subjects having substantial public interest.

- TECHNICAL TRANSLATION. Englishlanguage translations of foreign scientific and technical material pertinent to NASA's mission.

Specialized services that complement the STI Program Office's diverse offerings include creating custom thesauri, building customized databases, organizing and publishing research results ... even providing videos.

For more information about the NASA STI Program Office, see the following:

- Access the NASA STI Program Home Page at http://www.sti.nasa.gov

- E-mail your question via the Internet to help@sti.nasa.gov

- Fax your question to the NASA Access Help Desk at 301-621-0134

- Telephone the NASA Access Help Desk at 301-621-0390

- Write to:

NASA Access Help Desk

NASA Center for AeroSpace Information 7121 Standard Drive

Hanover, MD 21076 
NASA/TM-2004-213183

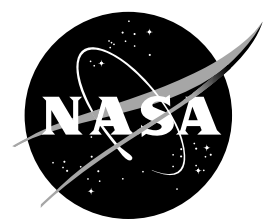

\section{Evaluation of High Temperature Knitted Spring Tubes for Structural Seal Applications}

Shawn C. Taylor

Case Western Reserve University, Cleveland, Ohio

Jeffrey J. DeMange

University of Toledo, Toledo, Ohio

Patrick H. Dunlap, Jr. and Bruce M. Steinetz

Glenn Research Center, Cleveland, Ohio

Prepared for the

40th Joint Propulsion Conference and Exhibit

cosponsored by the AIAA, ASME, SAE, and ASEE

Fort Lauderdale, Florida, July 11-14, 2004

National Aeronautics and

Space Administration

Glenn Research Center 
Available from

NASA Center for Aerospace Information 7121 Standard Drive

Hanover, MD 21076
National Technical Information Service 5285 Port Royal Road Springfield, VA 22100

Available electronically at http://gltrs.grc.nasa.gov 


\title{
Evaluation of High Temperature Knitted Spring Tubes for Structural Seal Applications
}

\author{
Shawn C. Taylor \\ Case Western Reserve University \\ Cleveland, Ohio 44106 \\ Jeffrey J. DeMange \\ University of Toledo \\ Toledo, Ohio 43606 \\ Patrick H. Dunlap, Jr. and Bruce M. Steinetz \\ National Aeronautics and Space Administration \\ Glenn Research Center \\ Cleveland, Ohio 44135
}

\begin{abstract}
Summary
Control surface seals are crucial to current and future space vehicles, as they are used to seal the gaps surrounding body flaps, elevons, and other actuated exterior surfaces. During reentry, leakage of high temperature gases through these gaps could damage underlying lower temperature structures such as rudder drive motors and mechanical actuators, resulting in impaired vehicle control. To be effective, control surface seals must shield lower temperature structures from heat transfer by maintaining sufficient resiliency to remain in contact with opposing sealing surfaces through multiple compression cycles. The current seal exhibits significant loss of resiliency after a few compression cycles at elevated temperatures (i.e., $1900^{\circ} \mathrm{F}$ ) and therefore would be inadequate for advanced space vehicles. This seal utilizes a knitted Inconel X-750 spring tube as its primary resilient element. As part of a larger effort to enhance seal resiliency, researchers at the NASA Glenn Research Center performed high temperature compression testing (up to $2000{ }^{\circ} \mathrm{F}$ ) on candidate spring tube designs employing material substitutions and modified geometries. These tests demonstrated significant improvements in spring tube resiliency $(5.5 \mathrm{x}$ better at $1750^{\circ} \mathrm{F}$ ) through direct substitution of heat treated Rene 41 alloy in the baseline knit design. The impact of geometry modification was minor within the range of parameters tested, however trends did suggest that moderate resiliency improvements could be obtained by optimizing the current spring tube geometry.
\end{abstract}

\section{Introduction}

High temperature seals play an important role in protecting the vital components of reusable space vehicles from the extreme environmental conditions experienced during reentry. Due to the continual increase in performance requirements for current and future space vehicles, the reliability of control surface seals is critical, as they are needed to minimize the ingestion of hot gases through the gaps surrounding actuated structures such as body flaps and elevons. In-flight failure of control surface seals could have detrimental effects on guidance and could potentially lead to the catastrophic loss of both the vehicle and crew. For this reason, control surface seals must continually evolve to adequately satisfy the rigorous demands of reentry. To address this need, a program for developing advanced control surface seals and seal systems for use on future reusable space vehicles has been established. 


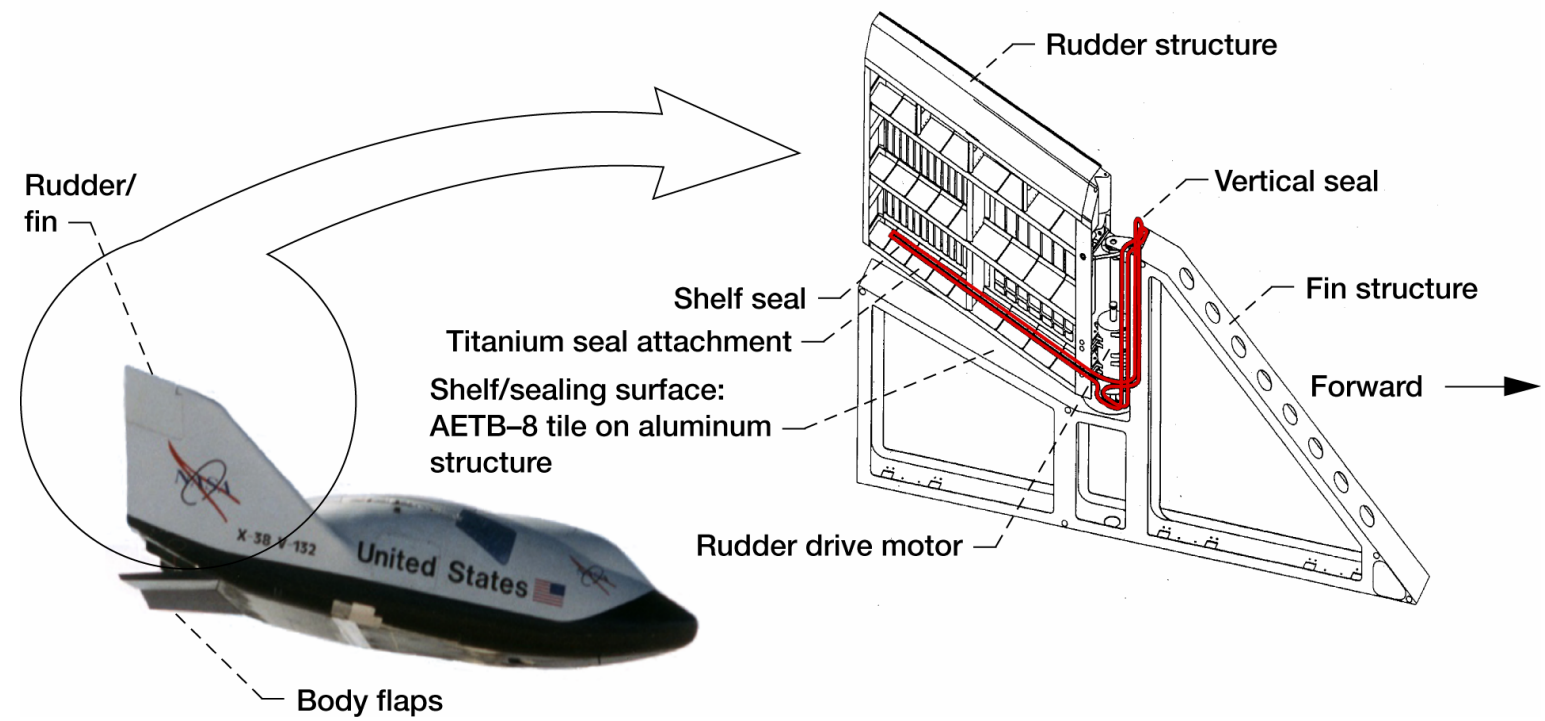

Figure 1.-Schematic of (a) X-38 Crew Return Vehicle. (b) Rudder/fin structure and seal locations.

The current baseline control surface seal has its origin as the rudder-fin seal for the X-38 crew return vehicle (CRV) and before that as a thermal barrier for several locations on the Space Shuttle. On the Space Shuttle, the baseline seal is used as a thermal barrier around the main landing gear doors, the payload bay door vents, and the orbiter external tank umbilical door. On the X-38, the seal was installed at the interface between the rudders and their respective fins (fig. 1). These seals are intended to prevent hot gas ingestion during reentry at the moving panel interfaces and to minimize heat transfer to underlying temperature intolerant structures (rudder drive motors, mechanical actuators, etc.). Previous tests demonstrated that the baseline seal design has limited effectiveness at high temperatures (i.e., $1900{ }^{\circ} \mathrm{F}$ ) due to loss of resiliency and therefore requires improvement in order to be used on next generation launch vehicles. ${ }^{1}$

\section{Seal Design Requirements}

The hostile reentry environment that future space vehicles must endure generates a stringent set of design requirements for future control surface seals. To ensure vehicle structural integrity, seals must survive at temperatures as high as 1800 to $2200{ }^{\circ} \mathrm{F}$ and restrict hot gas leakage to underlying temperature intolerant structures. Control surface seals are typically installed in a compressed state to compensate for both opening and closing of gaps due to thermal changes and/or mechanical actuation of the surfaces. During reentry, the seals must maintain sufficient resiliency to remain in contact with both sealing surfaces after multiple high temperature exposures. In addition to temperature based demands, other design challenges stem from contact surface characteristics. Surfaces such as Shuttle tiles are unable to withstand high compressive loads and therefore seals must be designed to minimize applied contact forces. Also, Shuttle tiles and ceramic matrix composite (CMC) surfaces typically used on control surface structures are often rough in their as-fabricated state. These panels commonly have surface roughness values on the order of 515 to $574 \mu \mathrm{in}$. RMS, and if left unfinished they can lead to excessive seal damage. ${ }^{2}$ As control surface structures are actuated during normal operation, seals are swept across the potentially rough contact surfaces. To maintain functionality, advanced seal designs must possess enough wear resistance to withstand this scrubbing action. The goal of researchers at NASA's GRC is to develop advanced control surface seal designs that can adequately accommodate all of the design requirements summarized in table 1. 
TABLE 1.-CONTROL SURFACE SEAL DESIGN REQUIREMENTS

\begin{tabular}{|l|c|}
\hline \multicolumn{1}{|c|}{ Parameter } & Design Requirement \\
\hline Seal temperature & Between $1800{ }^{\circ} \mathrm{F}$ and $2200{ }^{\circ} \mathrm{F}$ depending on vehicle application \\
\hline Maximum unit loads & $5 \mathrm{lbf} /$ in.-Shuttle tile (ref.3) \\
\hline Pressure drop across seal & $56 \mathrm{psf}$ to $100 \mathrm{psf}$ (ref.3) \\
\hline Leakage & Minimize \\
\hline Environment & Oxidizing environment \\
\hline Use of cooling & Operate without active cooling \\
\hline Time at maximum temperature & 1000 s to $2200 \mathrm{~s}(\sim 16$ min to 37 min)(ref. 3) \\
\hline Size & TBD-nominally 10 to 100 cycles \\
\hline Reusability & Thing nominal diamer \\
\hline Flexibility & Accommodate structural non-uniformities and seal around corners \\
\hline Resiliency & Accommodate seal gap openings and closings \\
\hline Seal gap size & Nominally 0.25 in. \\
\hline Sliding speed & Up to 8 in./sec \\
\hline Wear resistance & Withstand scrubbing against rough surfaces \\
\hline
\end{tabular}

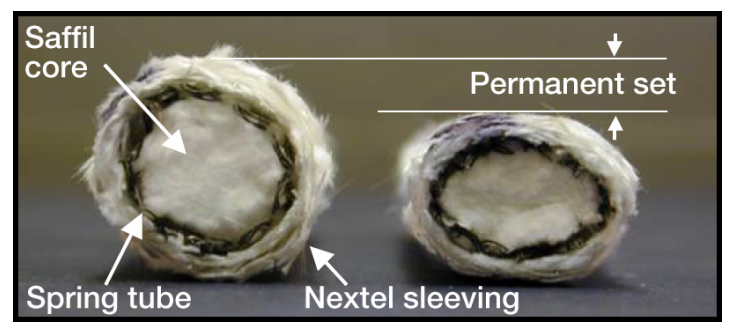

Figure 2.-Photograph of current baseline control surface seal before (left) and after (right) compression during $1900{ }^{\circ} \mathrm{F}$ exposure showing loss of seal resiliency. Initial seal diameter is approximately 0.62 in.

\section{Baseline Seal Design}

The baseline control surface seal is comprised of an Inconel X-750 spring tube stuffed with Saffil batting and overbraided with two layers of Nextel 312 ceramic sleeving (fig. 2). The spring tube is the primary resilient element and is fabricated using three parallel strands of Inconel wire which are knitted in a repeating looped pattern to form an open ended tube. The tube is then stuffed with the Saffil batting to limit the passage of hot gases through the seal, and overbraided with two layers of Nextel 312 ceramic fabric. The Nextel fabric provides a uniform surface for sealing, acts as a thermal barrier, and prevents the loss of Saffil batting through the wall of the spring tube.

An investigation into the performance of the baseline seal by Dunlap, et al. ${ }^{1}$ showed that when the seal was compressed and heated to $1900^{\circ} \mathrm{F}$, the seal suffered a significant loss of resiliency and exhibited a large permanent set (fig. 2). This loss of resiliency was attributed to the temperature dependent yield strength of the Inconel X-750 spring tube material. Further elevated temperature investigations at GRC by DeMange, et al. $^{4}$ on the Inconel spring tube itself yielded similar results. Compression testing at temperatures above approximately $1200^{\circ} \mathrm{F}$ produced significant reductions in spring tube resiliency and permanent set was clearly visible. As previously suspected, the temperature at which permanent set in the spring tubes became evident mirrored the temperature dependent yield strength behavior of the Inconel $\mathrm{X}-750$ alloy. However, at high temperatures, permanent set in these spring tubes is likely a combination of yielding and creep, but it is currently unknown which is the dominant mechanism. Based on these observations, the goals of this study were to (1) better understand the impact of spring tube geometry modifications and how they might be used to enhance resiliency and (2) evaluate potential improvements in the spring tube preloading component through material substitution. 


\section{Spring Tube Improvement}

Knit Geometry.-The knitted geometry of the existing spring tube is shown schematically in figure 3 and is herein referred to as the ST-5 design (as defined in Boeing specification MB0160-047). ${ }^{5}$ Spring tube knit geometry is described by the following set of parameters: number of wire strands, courses per inch $(\mathrm{CPI})$, needles $(\mathrm{N})$, wire diameter, and spring tube major diameter. These parameters can be defined as follows:

- Number of wire strands - the number of individual wires oriented in a parallel configuration that are simultaneously knitted to form the spring tube

- $\mathrm{CPI}$ - the number of individual loops (lengthwise) per inch of spring tube length

- $\quad \mathrm{N}$ - the number of individual loops counted along a single rotation about the circumference of the spring tube

- Wire diameter - the diameter of the individual strands of wire used in fabrication

- Tube major diameter - the outer diameter of the spring tube.

The baseline ST-5 design uses 3 wire strands (each 0.009 in. diameter) which are knitted to form a $0.560 \pm 0.025$ in. diameter tube with $10 \mathrm{~N}$ and $4.9 \mathrm{CPI}$.

To simplify the comparison of spring tubes fabricated using different geometries, a loop density (LD) was calculated for each design. The loop density, which estimates the number of loops per square inch, was defined using the following equation:

$$
\text { Loop Density } \equiv \frac{\text { CPI } * N}{\pi * \text { Tube Diameter }} \quad\left[\frac{\text { loops }}{\text { in. }^{2}}\right]
$$

For the present investigation, different combinations of loop density and number of wire strands were tested to determine their influence on spring tube resiliency and whether further evaluations through a more structured design of experiments (DOE) were necessary.

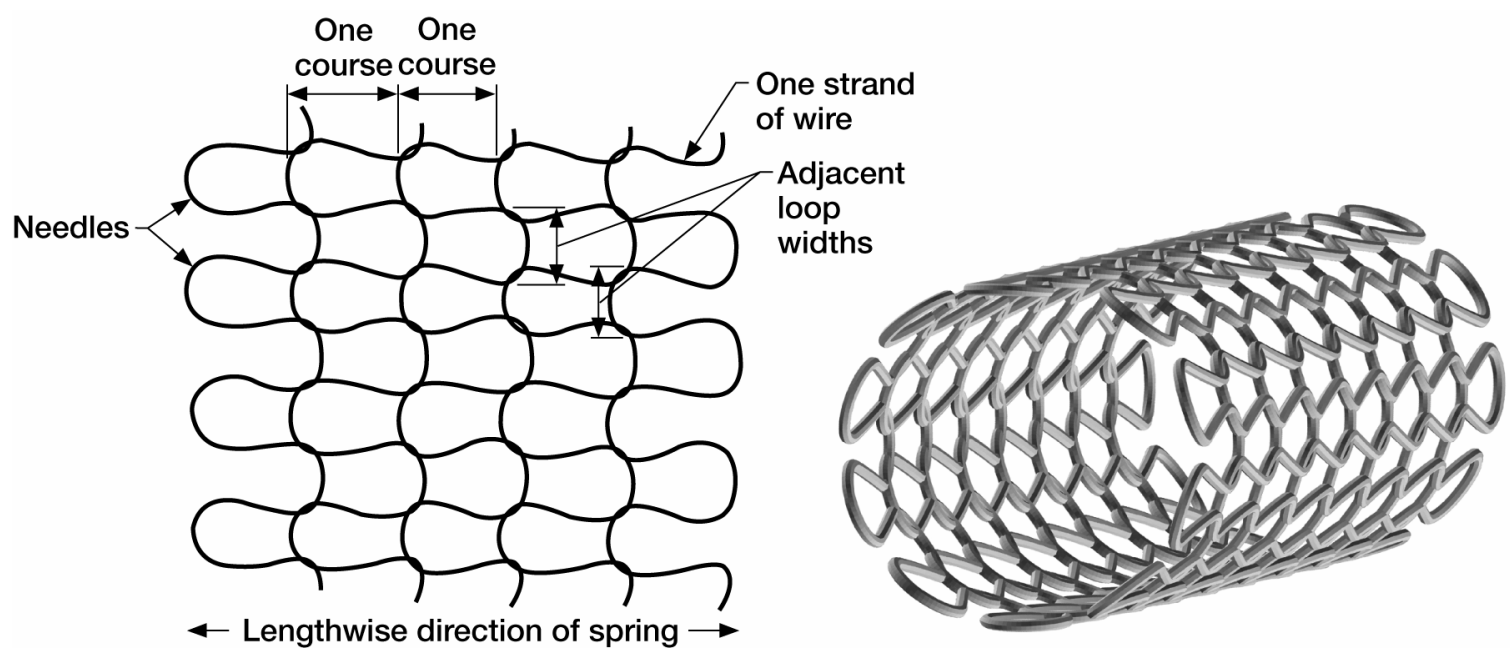

Figure 3.-(a) Schematic of spring tube geometry parameters. (b) Computer generated image depicting 3-dimensional spring tube geometry. 
Material Selection.-Previous observations of resiliency loss in the Inconel X-750 spring tube at elevated temperatures paralleled the high temperature yield strength behavior of this alloy. ${ }^{1,3,4}$ This suggested that high temperature resiliency could be significantly improved by selecting a spring tube material that possessed better high temperature yield strength and resistance to creep deformation. A list of candidate materials was compiled on the basis of high temperature yield strength, creep resistance, and availability of the material in wire form. Initially, oxide dispersion strengthened (ODS) alloys were selected as potential candidates due to their sustained high temperature strength properties. However, due to the difficulty and cost of obtaining the materials in wire form, a more readily available alloy, Rene 41, was selected for the near term. As shown in figures 4 and 5, Rene 41 has high temperature yield strength and creep resistance properties superior to those of the baseline Inconel X-750 alloy. This alloy also exhibits better yield strength properties than the ODS alloys up to approximately $1900^{\circ} \mathrm{F}$.

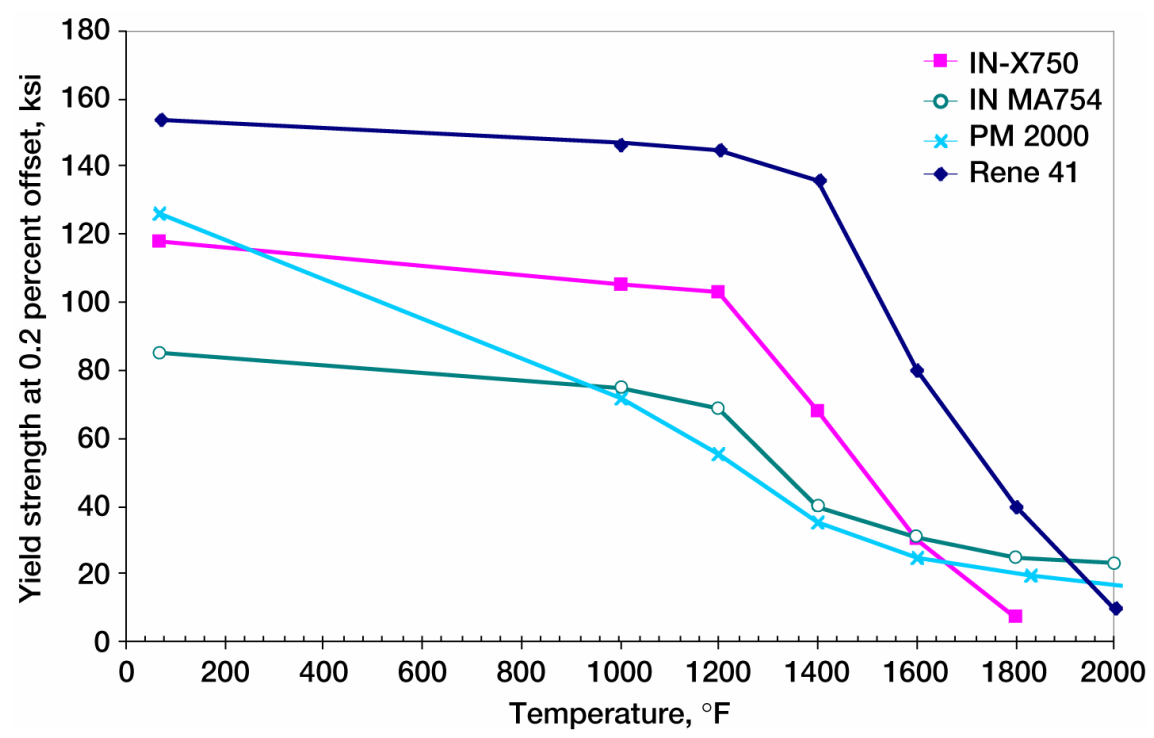

Figure 4.-Temperature dependent yield strength values for candidate materials. ${ }^{6-9}$

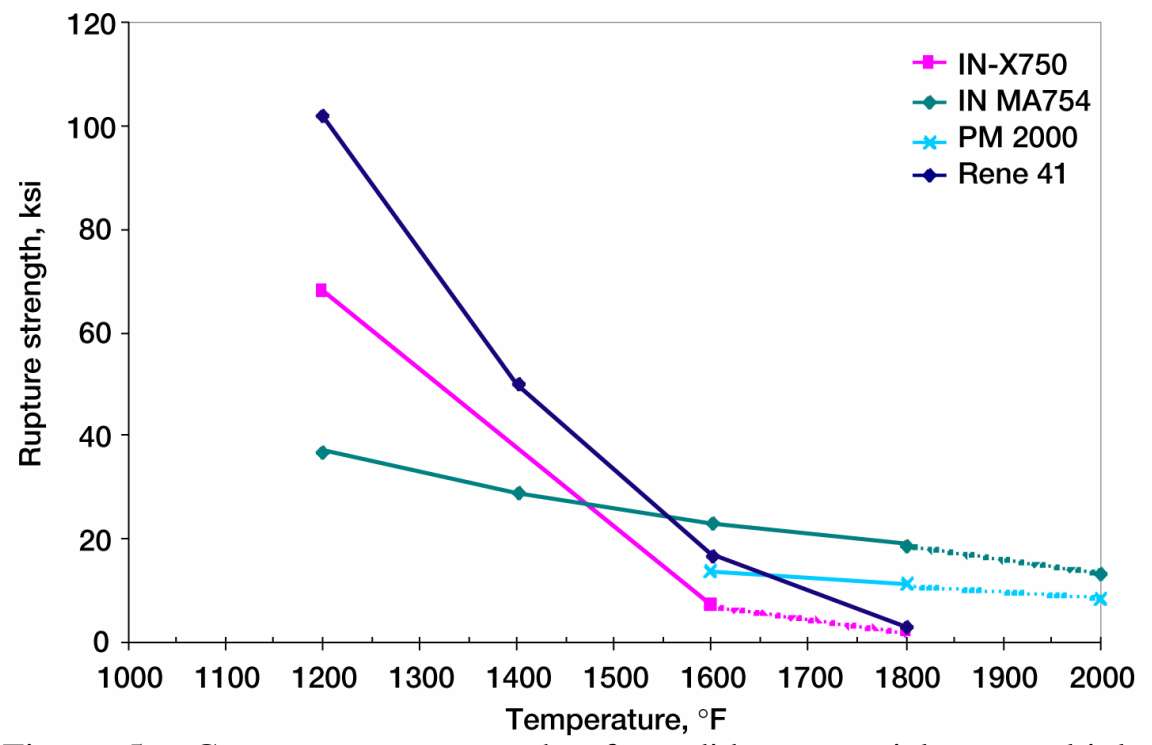

Figure 5.-Creep rupture strength of candidate materials at multiple temperatures. Note: The dashed lines represent estimated values in higher temperature regions. ${ }^{6-9}$ 
The high temperature strength of these alloys is significantly affected by thermal processing. Baseline Inconel X-750 spring tubes are heat treated as prescribed by Aerospace Materials Specification (AMS) 5698 for a number one temper wire $\left(1350{ }^{\circ} \mathrm{F}\right.$ for $\left.16 \mathrm{hr}\right)$. This heat treatment facilitates precipitation hardening of the Inconel X-750 alloy. For the current investigation, bright annealed Rene 41 wire was knitted into approximately $20 \mathrm{ft}$ of ST-5 spring tube. The tube was then heat treated using a two step procedure that included a solution heat treatment followed by an aging heat treatment. The solution heat treatment, conducted at $2050{ }^{\circ} \mathrm{F}$ for 30 minutes, was followed by controlled cooling of the material to below $800{ }^{\circ} \mathrm{F}$ in a nitrogen atmosphere. Once the material temperature was reduced to $800{ }^{\circ} \mathrm{F}$, the metal was reheated, aged at $1650{ }^{\circ} \mathrm{F}$ for one hour, and then cooled back to room temperature over a two hour period in a nitrogen atmosphere. This process resulted in precipitation hardening of the Rene 41 alloy thereby enhancing its yield strength properties.

\section{Test Equipment and Procedures}

\section{Spring Tube Test Specimens}

Spring tube samples of Inconel-X750 with different knit geometries and Rene 41 with the standard ST-5 knit geometry were used for this investigation. The material and geometry combinations tested in this study are presented in table 2 . The spring tubes had a nominal outer diameter of $0.560 \pm 0.025 \mathrm{in}$. and were cut to a nominal $4 \mathrm{in}$. length. These specimens were then tested at multiple temperature and compression levels to determine the effects that the modifications to the baseline spring design had on resiliency. To evaluate the effect of heat treatment on spring tube resiliency, spring tubes were tested in both an as-fabricated (cold worked) and a heat treated state.

TABLE 2.-SUMMARY OF EXPERIMENTAL SPRING TUBE SAMPLES TESTED

\begin{tabular}{|l|c|c|c|c|c|c|c|}
\hline \multicolumn{1}{|c|}{ Specimen Identifier } & Material & $\begin{array}{c}\text { Heat } \\
\text { Treatment }\end{array}$ & $\begin{array}{c}\text { Wire } \\
\text { Strands }\end{array}$ & $\begin{array}{c}\text { Wire } \\
\text { Diameter (in.) }\end{array}$ & CPI & Needles & $\begin{array}{c}\text { LD } \\
\text { (loops/in. }{ }^{\mathbf{2}} \text { ) }\end{array}$ \\
\hline Inconel ST-5 (HT) & Inconel X-750 & Yes & 3 & 0.009 & 4.9 & 10 & 28 \\
\hline Inconel ST-5 (NHT) & Inconel X-750 & No & 3 & 0.009 & 4.9 & 10 & 28 \\
\hline Inconel 34 LD (HT) & Inconel X-750 & Yes & 1 & 0.009 & 6 & 10 & 34 \\
\hline Inconel 34 LD (NHT) & Inconel X-750 & No & 1 & 0.009 & 6 & 10 & 34 \\
\hline Inconel 64 LD (HT) & Inconel X-750 & Yes & 1 & 0.009 & 7 & 16 & 64 \\
\hline Inconel 64 LD (NHT) & Inconel X-750 & No & 1 & 0.009 & 7 & 16 & 64 \\
\hline Rene ST-5 (HT) & Rene 41 & Yes & 3 & 0.009 & 4.9 & 10 & 28 \\
\hline Rene ST-5 (NHT) & \multicolumn{7}{|c|}{ Rene 41 No } \\
\hline
\end{tabular}

\section{Test Equipment}

Compression testing of the spring tube samples was conducted using a state-of-the-art test rig. A detailed description of this test rig can be found in Dunlap, et al., ${ }^{10}$ but a summary is included here for completeness. Using a combination of monolithic silicon carbide (Hexaloy $\alpha$-SiC) test fixtures that can withstand the elevated testing temperatures, the test rig is capable of performing either cyclic compression or scrub tests at temperatures up to $3000{ }^{\circ} \mathrm{F}$. The primary components of the test rig include an servo hydraulic load frame, an air furnace capable of $3000^{\circ} \mathrm{F}$, and a non-contact laser extensometer (fig. 6). The $500 \mathrm{lb}$ load cell used in this study was calibrated to a $\pm 100 \mathrm{lb}$ range with an accuracy of $\pm 0.04 \mathrm{lb}$ 


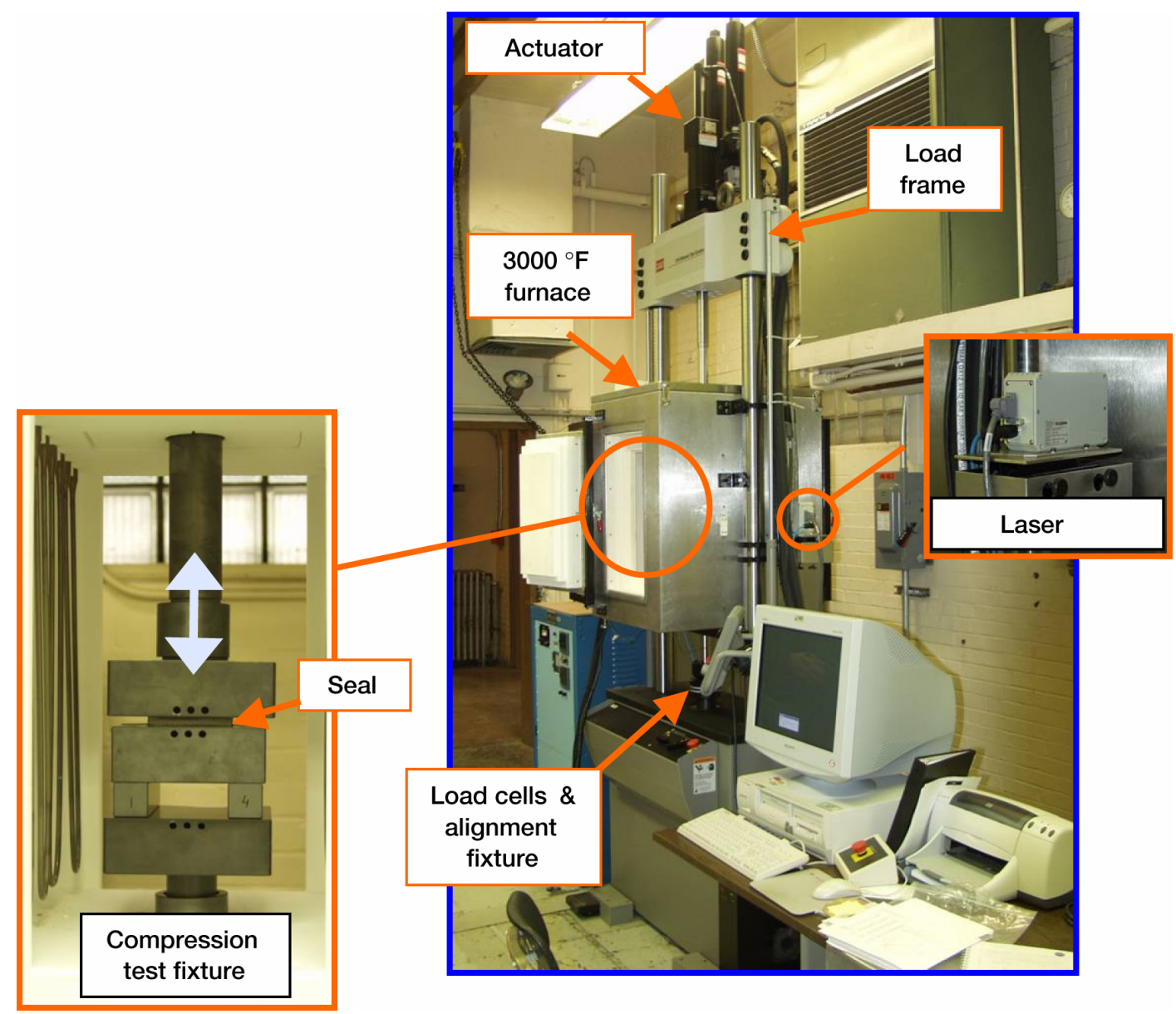

Figure 6.-Photographs of the hot compression test rig illustrating main components: load frame, high temperature furnace, laser extensometer, and high temperature compression fixturing.

( \pm 0.04 percent of full scale), and the laser extensometer had an accuracy of \pm 0.00025 in. Compression tests were performed inside the furnace utilizing the test setup shown in figure 6 . These tests were run under displacement control to determine the resiliency of the spring tube samples and to generate load vs linear compression data at both room and elevated temperatures (up to $2000{ }^{\circ} \mathrm{F}$ ). The laser extensometer was used to measure the amount of linear compression that was applied to the test specimens.

\section{Test Procedure}

Knit Geometry Screening Tests.- - To estimate the effects of geometry modifications on the candidate spring tube samples, a screening matrix of compression tests conducted at both room temperature $\left(70{ }^{\circ} \mathrm{F}\right)$ and $1500{ }^{\circ} \mathrm{F}$ was utilized. Due to a limited supply of samples and scheduling conflicts, repeat experiments were not conducted. The test specimens used in this screening matrix included both heat treated and asreceived samples of the Inconel ST-5, the Inconel $34 \mathrm{LD}$, and the Inconel $64 \mathrm{LD}$ spring tubes, as described in the Test Specimen section. Tested spring tube samples were supported using a flat platen. Although a grooved seal holder is typically used in compression testing of seal components, the flat platen was substituted to simplify contact constraint conditions to facilitate future numerical modeling efforts. At the beginning of each test, initial contact between the test specimen and the loading platen was 
defined when the load on the specimen reached a specified preload value of $0.2 \mathrm{lbf}(0.05 \mathrm{lbf} / \mathrm{in}$.). The samples were then compressed to 80 percent of their nominal diameter ( 0.112 in. deflection stroke) at a loading rate of $0.002 \mathrm{in./s}$, held for a dwell period of 250 seconds at maximum compression, and then fully unloaded at the same rate. The loading, dwell, and unloading cycle was repeated 10 times.

Material Selection Tests.-Compression tests were also conducted on both heat treated and asreceived (non heat treated) samples of the Inconel X-750 ST-5 and Rene 41 ST-5 spring tubes in order to assess the effects of material selection and heat treat condition on performance. These tests were performed using similar parameters (i.e., compression levels, dwell times, etc.) as those specified in the previous section with the following exceptions: In order to provide a more comprehensive evaluation of material effects, these cyclic tests were conducted using 20 compression cycles, and a grooved seal holder that is more representative of anticipated flight conditions. To determine the temperature where loss in resiliency occurred, tests were conducted at 5 different temperatures, including room temperature, $1200{ }^{\circ} \mathrm{F}, 1500{ }^{\circ} \mathrm{F}, 1750^{\circ} \mathrm{F}$, and $2000^{\circ} \mathrm{F}$. A single test was conducted at each temperature for the Inconel $\mathrm{X}-750$ specimens. A repeat test at each temperature was performed for the Rene 41 spring tubes.

\section{Data Analysis}

As previously discussed, high temperature resiliency has been identified as a key shortcoming of the current baseline seal design. To evaluate the resiliency of candidate seal specimens, high temperature cyclic compression tests were conducted with resiliency reported in terms of residual interference. Residual interference is a relative measure of how much a seal or seal component springs back after a given deflection (fig. 7). A residual interference of 100 percent indicates that a seal has taken on no permanent set due to previous compressions. A residual interference of 0 percent indicates the seal has taken on a permanent set equal to the last compressive stroke it endured.

Residual interference is calculated by subtracting the permanent set incurred from the maximum stroke applied by the loading platen. Note that the maximum stroke applied by the loading platen is nominally equal to the initial (Cycle 1) compression of the seal and is typically 20 percent of the specimen diameter. Permanent set incurred in a cycle is estimated by determining the point at which the monitored load begins to continually increase (i.e., platen/specimen contact occurs) during the subsequent compression cycle. In equation form, residual interference is defined as

$$
\left.\Gamma_{n} \equiv \Delta_{n-1}-\delta_{n} \quad \text { [in. }\right] \quad \text { or } \quad \hat{\Gamma}_{n} \equiv\left(\frac{\Delta_{n-1}-\delta_{n}}{\Delta_{n-1}}\right) * 100 \quad[\%]
$$

where $\Gamma_{n}$ is the residual interference at the beginning of cycle $n, \Delta_{n-1}$ is the maximum stroke applied by the platen during cycle $n-1$ (to account for any actuator drift), and $\delta_{n}$ is the permanent set in the sample as determined by the stroke magnitude when contact occurs. The normalized residual interference, $\hat{\Gamma}_{n}$, is calculated as a percentage relative to the compression stroke, $\Delta_{n-1}$. Residual interference was determined to be accurate to within 2 percent of the reported value.

Although this study did not include a formal design of experiments, techniques common to DOE analyses were used to highlight trends in the collected data. Effects plots were generated by graphing averaged response values related to a specific spring tube parameter. This allowed the influence of the individual parameter on spring tube performance to be isolated for evaluation. 


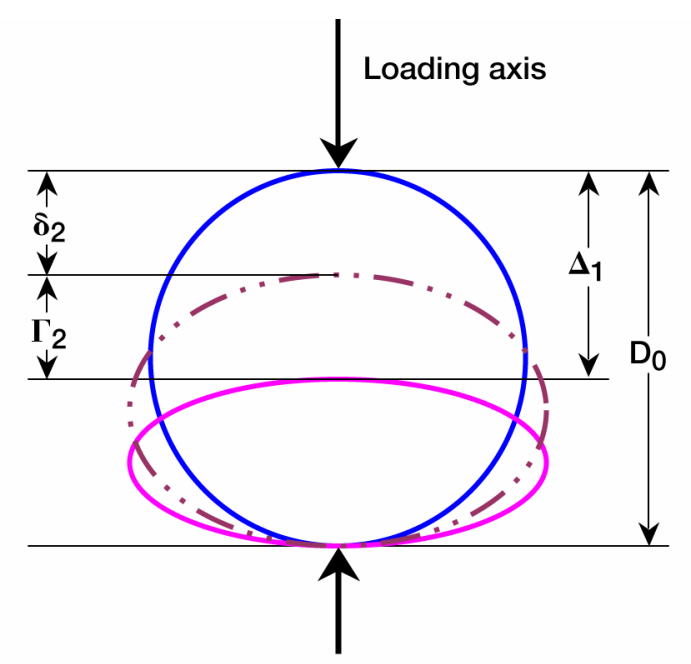

$\Delta_{1}=$ Nominal linear compression stroke

$\Gamma_{2}=$ Residual interference at cycle 2 start

$\delta_{2}=$ Permanent set at cycle 2 start

(a)

$D_{0}=$ Seal nominal diameter

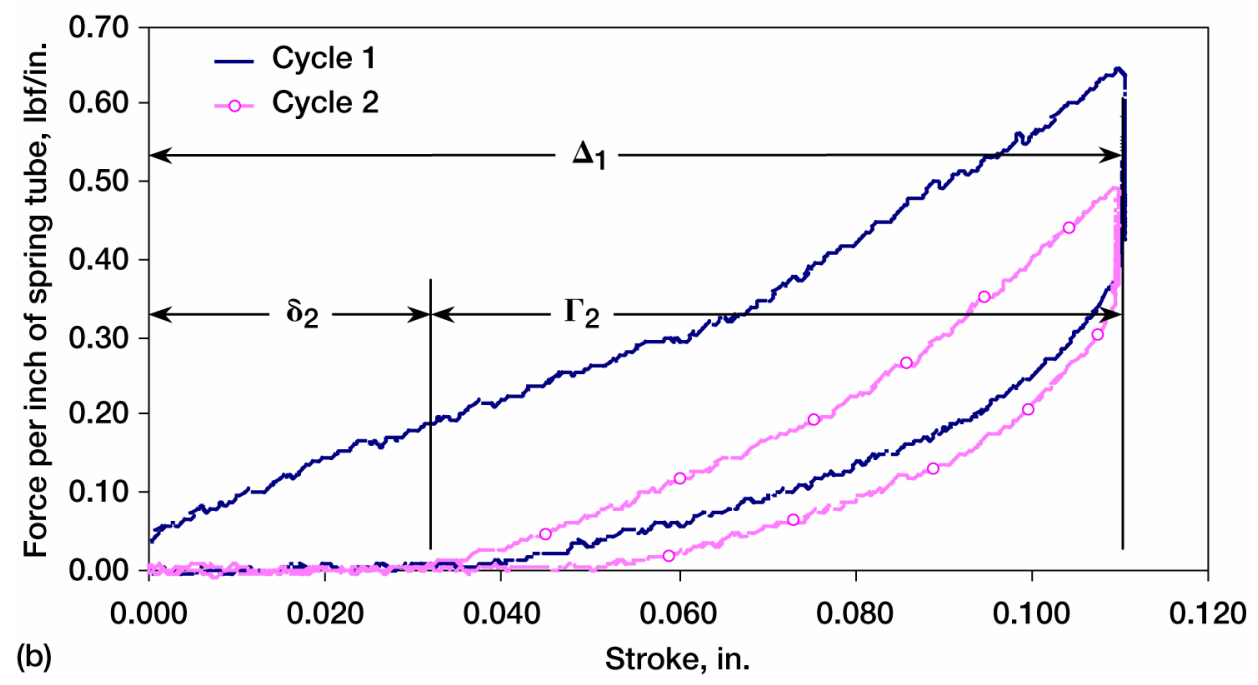

Figure 7.-(a) Spring tube schematic showing the determination of residual interference and (b) the corresponding plot of load vs stroke. 


\section{Results and Discussion}

\section{Knit Geometry Modification Effects}

A summary showing the impact of geometry modifications on spring tube performance is presented in table 3 for cycles 1, 2, 3, and 10 from the geometry screening matrix. The data includes peak load at dwell and residual interference values for the evaluated geometries at both room temperature $\left(70{ }^{\circ} \mathrm{F}\right)$ and $1500{ }^{\circ} \mathrm{F}$. In general, the geometry modifications tested had only a minor impact on resiliency. However, observed trends in the data did indicate that spring tube resiliency could be improved somewhat by optimizing the geometry parameters.

TABLE 3.-COMPRESSION TEST RESULTS FROM GEOMETRY EFFECTS SCREENING MATRIX

\begin{tabular}{|c|c|c|c|c|c|c|c|c|c|c|c|c|c|}
\hline \multirow[b]{2}{*}{ Cycle, $n$} & \multirow[t]{2}{*}{\begin{tabular}{|c|} 
Test \\
Temperature \\
$\left({ }^{\circ} \mathbf{F}\right)$ \\
\end{tabular}} & \multicolumn{4}{|c|}{ Peak Load at Dwell (lbf/in.) } & \multicolumn{4}{|c|}{$\begin{array}{c}\text { Residual Interference at start } \\
\text { of load cycle, } \Gamma_{n} \text { (in.) }\end{array}$} & \multicolumn{4}{|c|}{$\begin{array}{l}\text { Percent residual interference } \\
\text { at start of load cycle, } \hat{\Gamma}_{n}(\%)\end{array}$} \\
\hline & & 1 & 2 & 3 & 10 & 1 & 2 & 3 & 10 & 1 & 2 & 3 & 10 \\
\hline Inconel ST-5 (HT) & 70 & 0.86 & 0.84 & 0.84 & 0.82 & 0.112 & 0.111 & 0.111 & 0.111 & 100 & 100 & 100 & 100 \\
\hline Inconel ST-5 (HT) & 1500 & 0.42 & 0.30 & 0.26 & 0.14 & 0.112 & 0.083 & 0.090 & 0.042 & 100 & 75 & 81 & 38 \\
\hline Inconel ST-5 (NHT) & 70 & 0.78 & 0.77 & 0.77 & 0.74 & 0.112 & 0.112 & 0.112 & 0.112 & 100 & 100 & 100 & 100 \\
\hline Inconel ST-5 (NHT) & 1500 & 0.46 & 0.33 & 0.28 & 0.14 & 0.112 & 0.079 & 0.068 & 0.045 & 100 & 71 & 61 & 41 \\
\hline Inconel 34 LD (HT) & 70 & 0.29 & 0.30 & 0.30 & 0.30 & 0.112 & 0.112 & 0.112 & 0.112 & 100 & 100 & 100 & 100 \\
\hline Inconel $34 \mathrm{LD}(\mathrm{HT})$ & 1500 & 0.15 & 0.11 & 0.09 & 0.04 & 0.112 & 0.088 & 0.075 & 0.037 & 100 & 79 & 67 & 33 \\
\hline Inconel 34 LD (NHT) & 70 & 0.30 & 0.30 & 0.30 & 0.30 & 0.112 & 0.111 & 0.111 & 0.112 & 100 & 100 & 100 & 100 \\
\hline Inconel 34 LD (NHT) & 1500 & 0.18 & 0.13 & 0.11 & 0.06 & 0.112 & 0.094 & 0.076 & 0.048 & 100 & 84 & 68 & 43 \\
\hline Inconel 64 LD (HT) & 70 & 0.41 & 0.41 & 0.40 & 0.39 & 0.112 & 0.112 & 0.112 & 0.112 & 100 & 100 & 100 & 100 \\
\hline Inconel 64 LD (HT) & 1500 & 0.22 & 0.16 & 0.14 & 0.07 & 0.112 & 0.081 & 0.071 & 0.043 & 100 & 73 & 63 & 39 \\
\hline Inconel 64 LD (NHT) & 70 & 0.33 & 0.33 & 0.33 & 0.33 & 0.112 & 0.112 & 0.112 & 0.112 & 100 & 100 & 100 & 100 \\
\hline Inconel 64 LD (NHT) & 1500 & 0.19 & 0.14 & 0.13 & 0.07 & 0.112 & 0.095 & 0.093 & 0.060 & 100 & 85 & 83 & 54 \\
\hline
\end{tabular}

HT - Heat Treated NHT - Non Heat Treated LD - Loop Density

An analysis of the residual interference data collected for cycle 10 from the $1500{ }^{\circ} \mathrm{F}$ tests (table 3 ) showed that modifying the loop density had the largest impact on residual interference. As illustrated in figure $8(\mathrm{a})$, increasing the loop density from 34 to 64 resulted in an average increase of approximately 21 percent $\left(\left(\frac{46 \%-38 \%}{38 \%}\right) * 100\right)$ in percent residual interference, $\hat{\Gamma}_{n}$. Increasing the number of wire strands in the spring tube design from 1 strand to 3 produced an average resiliency decrease of approximately 7 percent (fig. 7(b)). However, due to the large spread of the averaged residual interference data and the small number of data points collected, this decrease is negligible.

A similar analysis was also used to evaluate the effects of geometry on the peak force generated during cycle 10 of the $1500{ }^{\circ} \mathrm{F}$ tests. Raising the loop density from 34 to 64 did not produce a substantial increase in the maximum loads (fig. 9(a)). Changing the number of strands from 1 to 3 more than doubled the peak force (fig. 9(b)). The peak forces generated by these changes are still well below the maximum acceptable value for shuttle tile applications. 

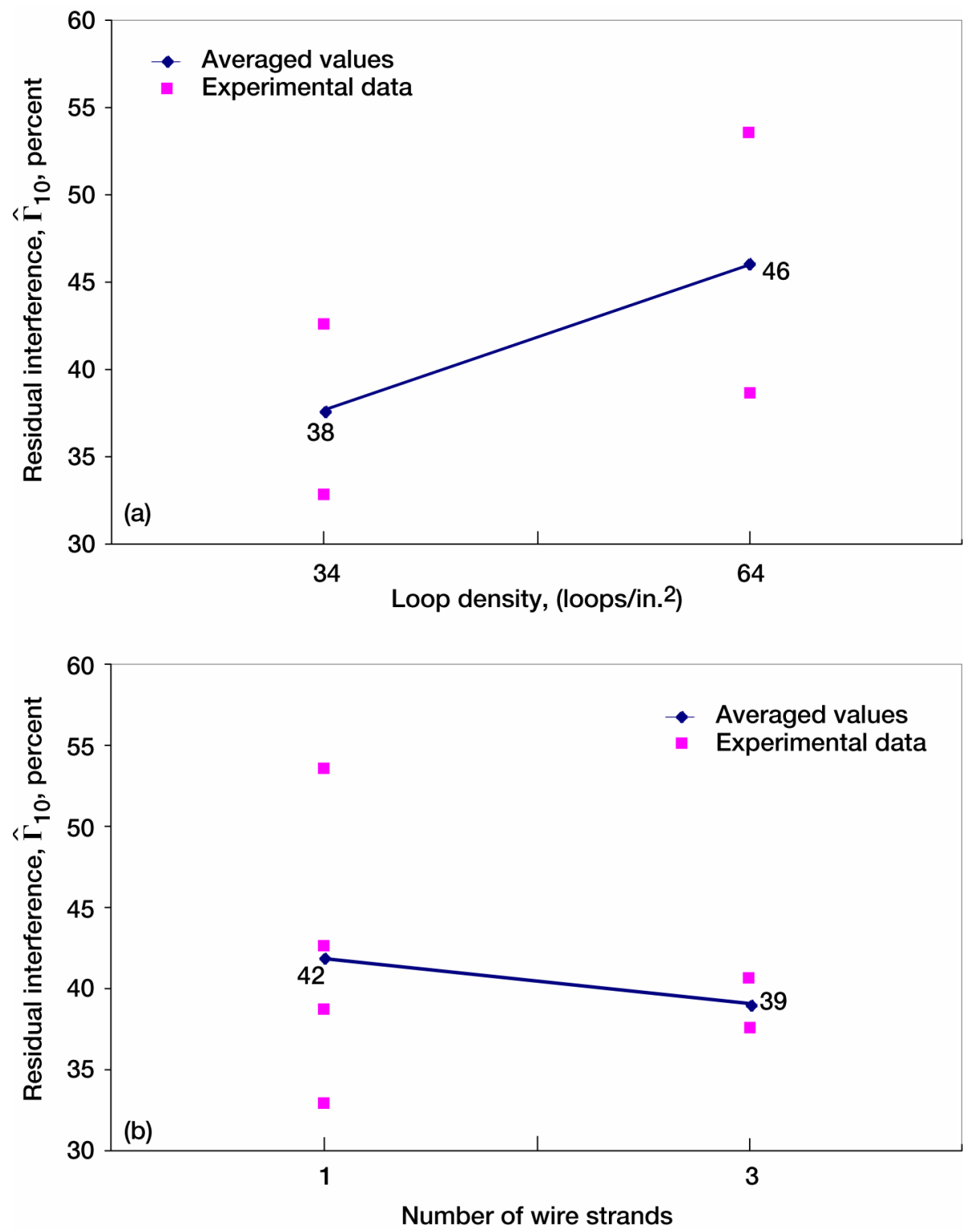

Figure 8.-Effects plots depicting the impact of (a) loop density and (b) number of strands, on average spring tube resiliency at the start of compression cycle 10. Data is from $1500{ }^{\circ} \mathrm{F}$ tests of Inconel X-750 specimens. 

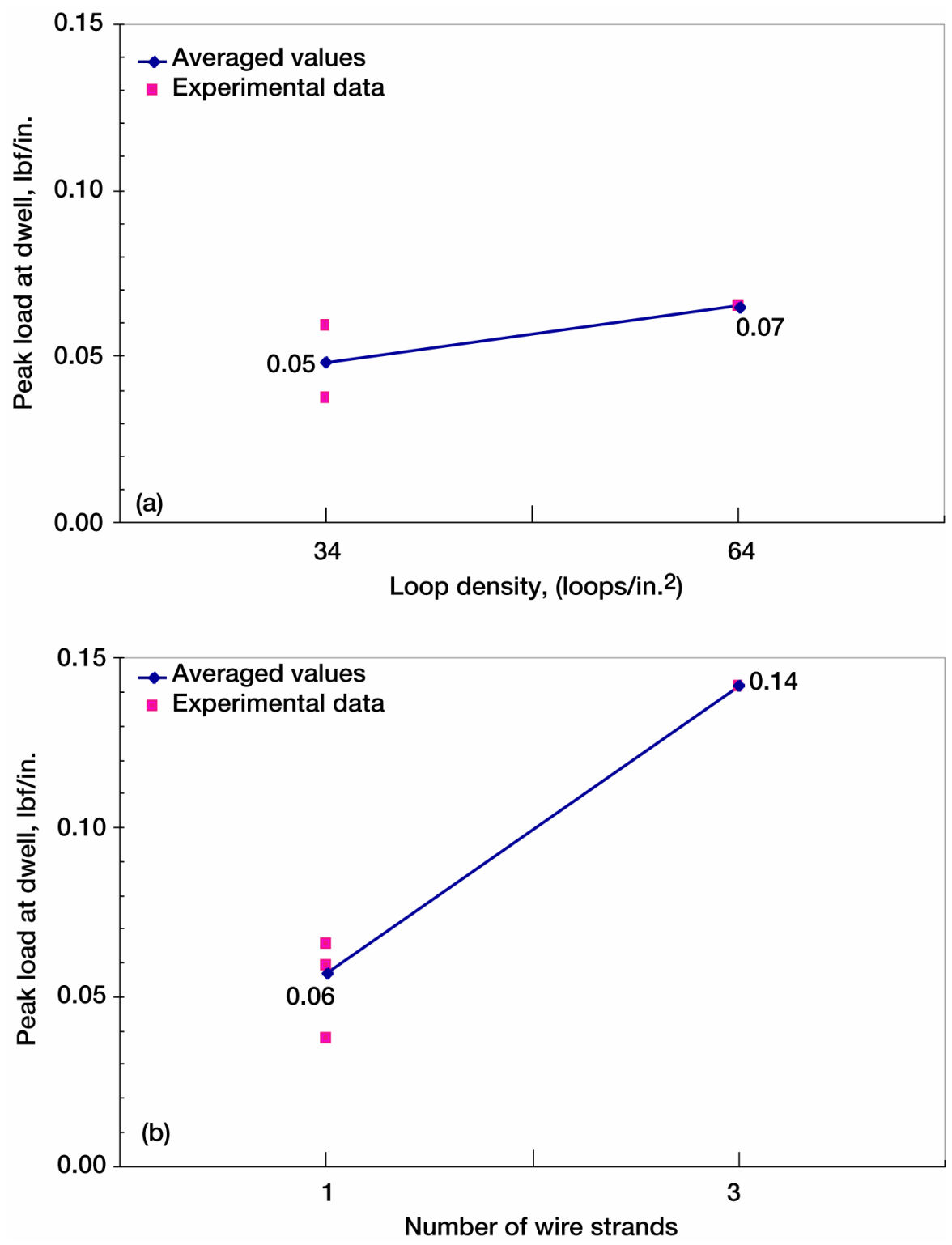

Figure 9.-Effects plots depicting the impact of (a) loop density and (b) the number of wire strands, on peak load at compression cycle 10. Presented data is from $1500^{\circ} \mathrm{F}$ tests of Inconel X-750 spring tube samples.

Material Effects.-Compression test data comparing the performance of the Rene 41 and Inconel X750 spring tubes is presented in table 4 . Note that the results shown are averaged values where repeat tests were performed. Figure 10 shows that the heat-treated Rene 41 spring tube specimens displayed significant improvements in high temperature resiliency over the heat treated Inconel X-750 spring tubes. The Rene 41 spring tube maintained greater than 95 percent resiliency during the 20 cycle tests through $1200{ }^{\circ} \mathrm{F}$. At $1500{ }^{\circ} \mathrm{F}$, the Rene ST-5 suffered a decrease in residual interference of approximately 16 percent. Despite this loss, the Rene 41 material still exhibited a 5.2x improvement in resiliency over the baseline design at the start of compression cycle 20. In contrast to the Inconel X-750 spring tube, the heat treated Rene 41 spring tube also maintained reasonable resiliency up to at least $1750{ }^{\circ} \mathrm{F}$. This result correlates with the material's high temperature yield strength behavior shown previously in figure 4. 
Substitution of Rene 41 for Inconel in the ST-5 geometry produced a significant increase in spring tube temperature capability, as highlighted in figure 11. For a sustained residual interference of 75 percent, Rene 41 samples showed a temperature improvement of approximately $275^{\circ} \mathrm{F}$ over the Inconel specimens.

TABLE 4.-COMPRESSION TEST RESULTS COMPARING RENE 41 AND INCONEL X-750

\begin{tabular}{|c|c|c|c|c|c|c|c|c|c|c|c|}
\hline \multirow{3}{*}{$\frac{\text { Temperature }\left({ }^{\circ} \mathbf{F}\right)}{\text { Cycle, } n}$} & \multicolumn{10}{|c|}{ Residual interference, $\hat{\Gamma}_{n}(\%)$} & \multirow{3}{*}{$\begin{array}{c}\text { Number of } \\
\text { Tests }\end{array}$} \\
\hline & \multicolumn{2}{|c|}{70} & \multicolumn{2}{|c|}{1200} & \multicolumn{2}{|c|}{1500} & \multicolumn{2}{|c|}{1750} & \multicolumn{2}{|c|}{2000} & \\
\hline & 2 & 20 & 2 & 20 & 2 & 20 & 2 & 20 & 2 & 20 & \\
\hline Inconel ST-5 (HT) & 98 & 98 & 93 & 78 & 61 & 16 & 13 & 0 & 5 & 0 & 1 \\
\hline Rene ST-5 (HT) & 100 & 96 & 98 & 97 & 99 & 83 & 72 & 28 & 9 & 0 & 2 \\
\hline \multirow[t]{2}{*}{ Rene ST-5 (NHT) } & 92 & 88 & 95 & 86 & 66 & 32 & 15 & 3 & 13 & 1 & 2 \\
\hline & \multicolumn{10}{|c|}{ Peak load at dwell (lbf/in.) } & \multirow{3}{*}{$\begin{array}{l}\text { Number of } \\
\text { Tests }\end{array}$} \\
\hline Temperature $\left({ }^{\circ} \mathbf{F}\right)$ & \multicolumn{2}{|c|}{70} & \multicolumn{2}{|c|}{1200} & \multicolumn{2}{|c|}{1500} & \multicolumn{2}{|c|}{1750} & \multicolumn{2}{|c|}{2000} & \\
\hline Cycle, $n$ & 1 & 20 & 1 & 20 & 1 & 20 & 1 & 20 & 1 & 20 & \\
\hline Inconel ST-5 (HT) & 0.78 & 0.77 & 0.87 & 0.70 & 0.64 & 0.11 & 0.29 & 0.00 & 0.43 & 0.00 & 1 \\
\hline Rene ST-5 (HT) & 0.98 & 0.93 & 1.03 & 0.87 & 1.00 & 0.69 & 0.65 & 0.17 & 0.29 & 0.00 & 2 \\
\hline Rene ST-5 (NHT) & 1.03 & 1.02 & 1.01 & 0.86 & 0.66 & 0.26 & 0.29 & 0.01 & 0.25 & 0.00 & 2 \\
\hline
\end{tabular}

HT - Heat Treated NHT - Non Heat Treated

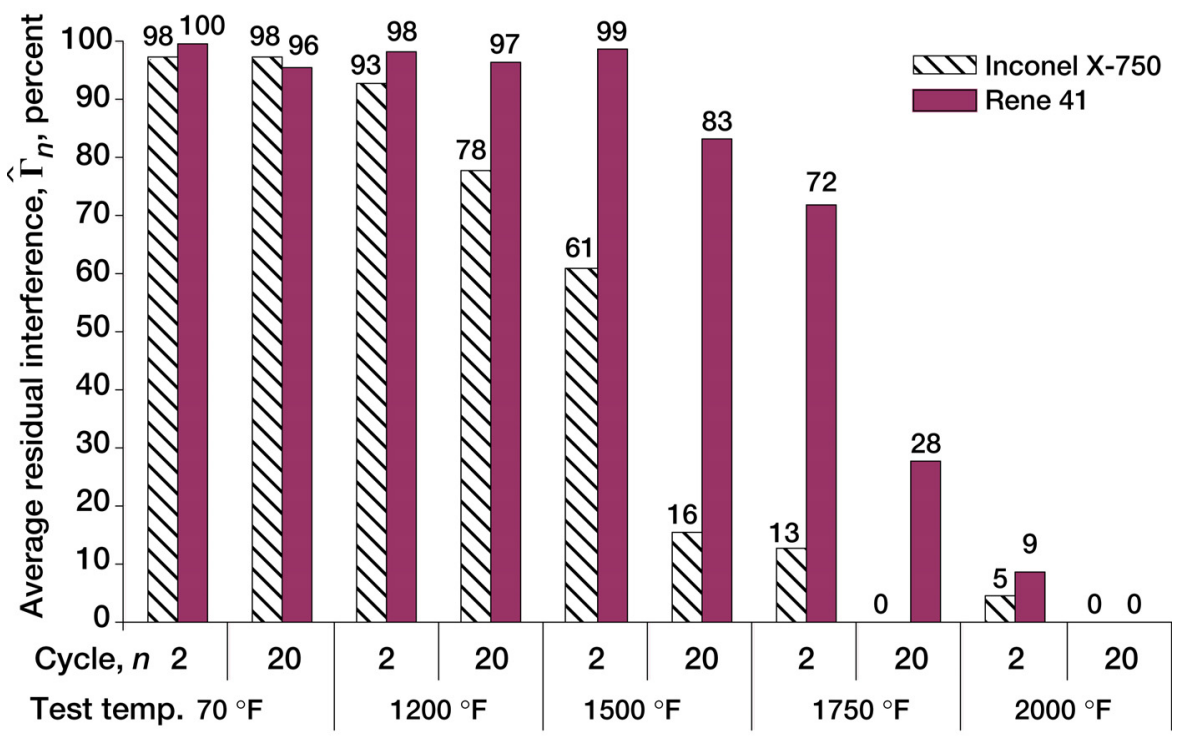

Figure 10.-Comparison of spring tube resiliency at the start of compression cycles 2 and 20 for heat treated samples of Inconel X-750 and Rene 41 using the ST-5 knit geometry at multiple test temperatures. 


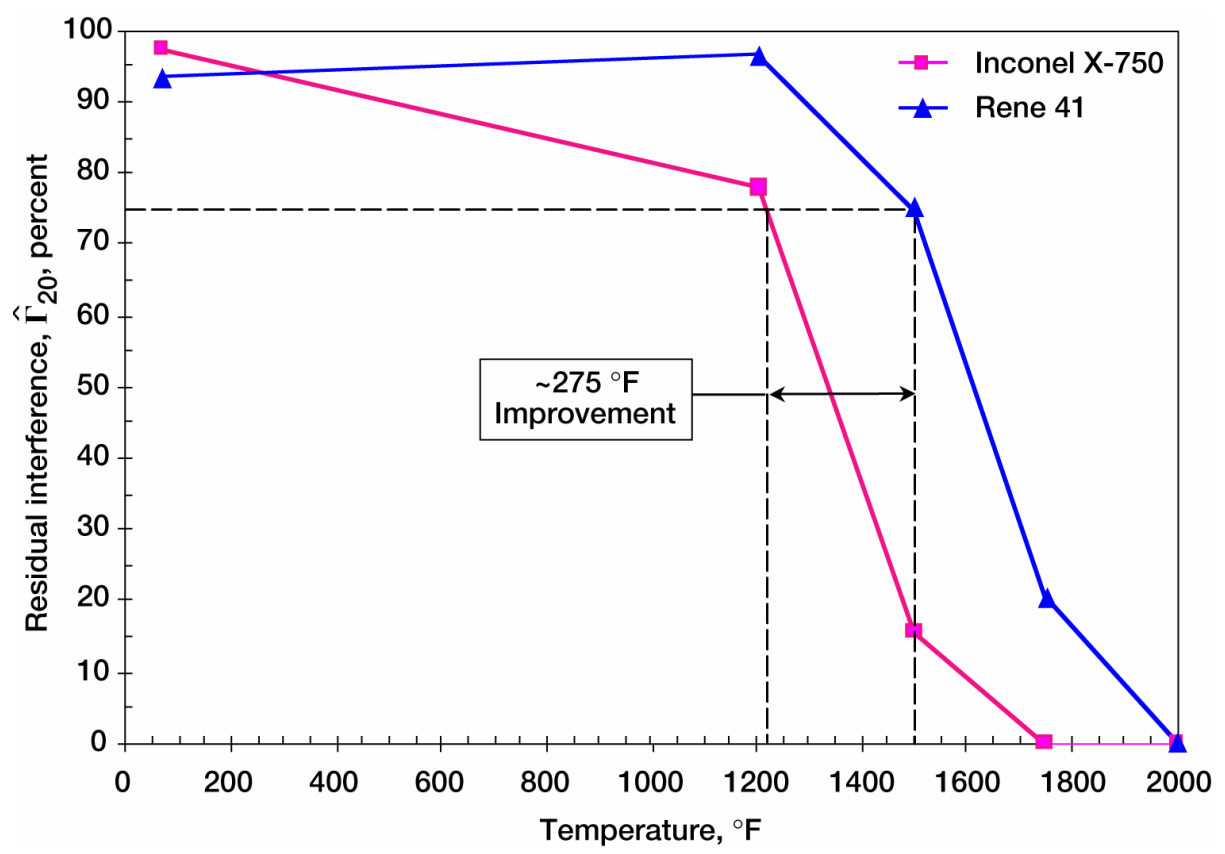

Figure 11.-Graph of resiliency vs test temperature at the start of compression cycle 20 for heat treated samples of Inconel X-750 and Rene 41 using ST-5 knit geometry.

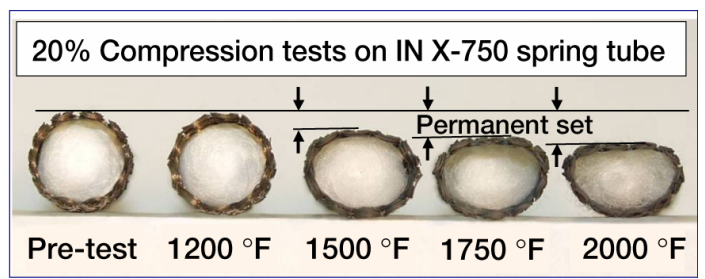

(a)

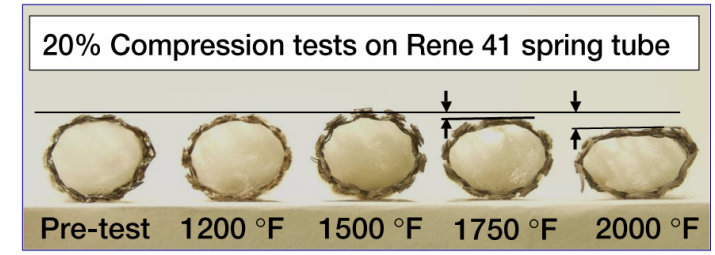

(b)

Figure 12.-Post test photographs showing permanent set in (a) heat treated Inconel X-750 and (b) heat treated Rene 41 ST-5 spring tubes at multiple test temperatures after 20 compression cycles.

Observed resiliency improvements were confirmed during post-test inspection of the spring tubes. As depicted in figures 12(a) and 12(b), permanent set in the Rene 41 samples was nearly undetectable until $1750{ }^{\circ} \mathrm{F}$, whereas permanent deformation was clearly evident in the Inconel samples at $1500{ }^{\circ} \mathrm{F}$.

As shown in table 4, the peak load produced by the heat treated Rene ST-5 spring tube at room temperature $(0.98 \mathrm{lbf} / \mathrm{in}$.) was approximately 26 percent higher than the peak load on the baseline design (0.78 lbf/in.). Previous studies on the full construction of the baseline seal (Nextel 312 sheath/IN X-750 
spring tube/saffil batting), which is stiffer than the spring tube itself, showed the peak loads to be around $2 \mathrm{lbf} / \mathrm{in} .{ }^{1}$ Assuming a 26 percent increase in contact force with the substitution of the Rene 41 spring tube, the load produced by a full seal construction would still be well below the $5 \mathrm{lbf} / \mathrm{in}$. maximum limit for Shuttle tiles. Future testing on control surface seals with the Rene 41 spring tube substitution will be needed to confirm this.

A comparison of the peak loads at cycle 20 for each spring tube material vs test temperature is presented in figure 13. From this plot, it is clear that the Rene ST-5 had much better resistance to load relaxation caused by repeated cycling than the Inconel ST-5. This is highlighted in the plot of load vs time during compression cycles 1 and 20 for both materials at $1500^{\circ} \mathrm{F}$ (fig. 14). As also demonstrated by this plot, the Rene 41 specimens exhibited better resistance to load relaxation during the dwell segments of the testing. For example, during the first cycle, the spring tube load decreased over 40 percent for the Inconel X-750 material and only approximately 17 percent for Rene 41.

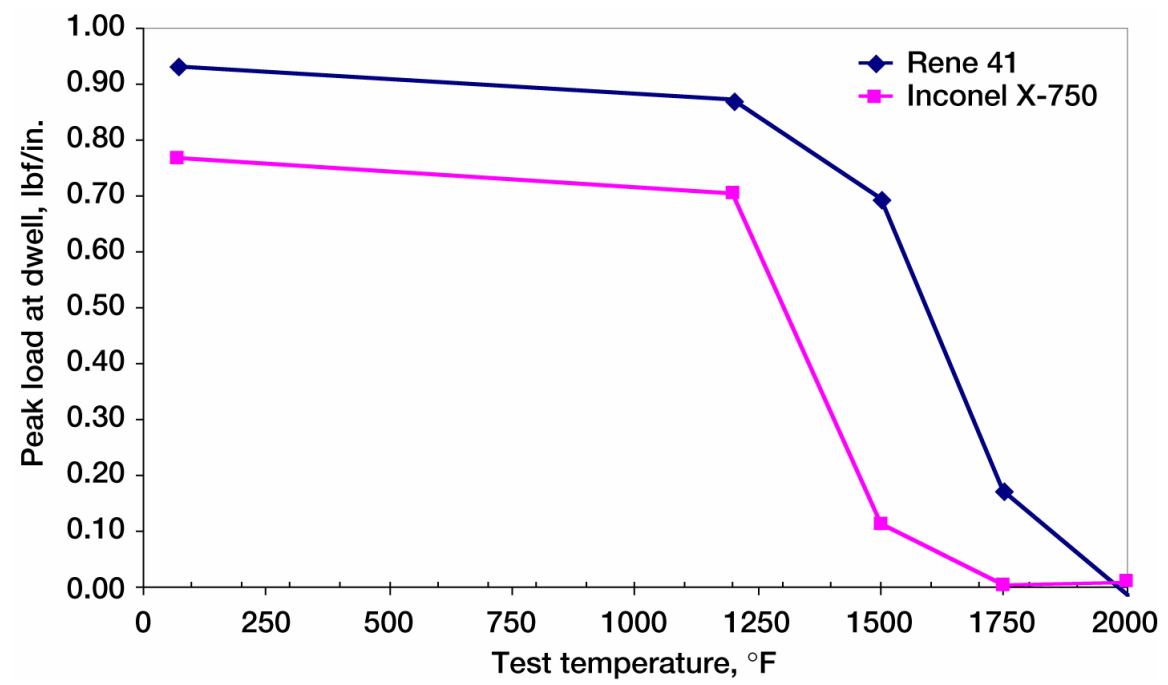

Figure 13.-Comparison of peak loads during compression cycle 20 for heat treated samples of Inconel X-750 and Rene 41 ST-5 spring tubes at multiple test temperatures.

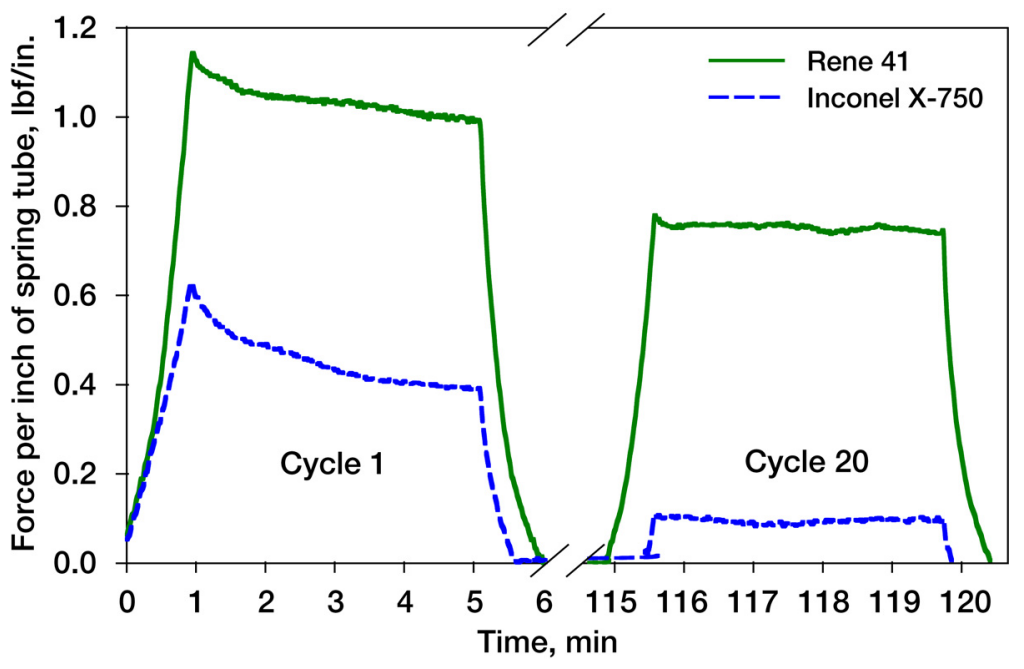

Figure 14.-Graph of load vs time during compression cycles 1 and 20 for heat treated samples of Inconel X-750 and Rene 41 ST-5 spring tubes at $1500{ }^{\circ} \mathrm{F}$. 

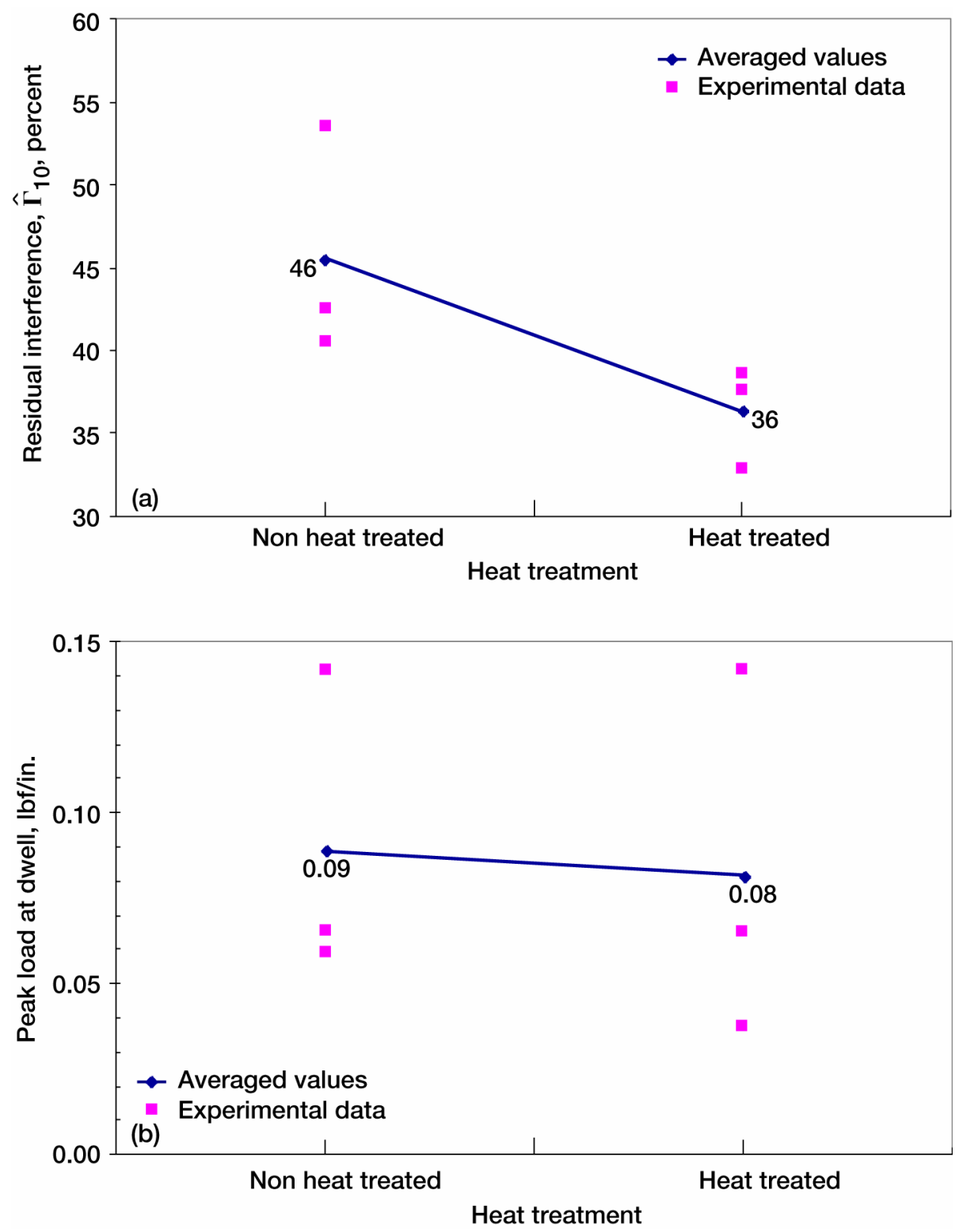

Figure 15.-Effects plots depicting the impact of heat treatment of the Inconel $\mathrm{X}-750$ spring tube on (a) average resiliency, and (b) average peak load, for compression cycle 10 at $1500^{\circ} \mathrm{F}$.

The effect of heat treatment on the spring tubes yielded different results for each of the two materials. Data collected for cycle 10 from screening tests on the Inconel X-750 samples showed that heat treating the spring tube decreased resiliency by approximately 22 percent and decreased the peak load at dwell by approximately $0.01 \mathrm{lbf} / \mathrm{in}$., or 11 percent (fig. 15). It is unclear why heat treatment of the Inconel spring tube decreased high temperature resiliency and peak loads. Loss of resiliency and load retention are primarily believed to be the result of decreased material yield strength at increased test temperatures. Based on this statement, heat treated Inconel samples should have demonstrated improved performance over non heat treated specimens, as heat treating enhances the high temperature yield properties of the Inconel X-750 material. 
In general, the effects of heat treatment on the Inconel samples were minor when compared to the results with the Rene ST-5. As shown in figures 16(a) and 16(b), the heat treated Rene ST-5 performed significantly better than the non heat treated samples, both in resiliency and load retention. At $1750{ }^{\circ} \mathrm{F}$, heat treated samples showed a 9.3x improvement in average resiliency over the non heat treated specimens, and a 17x increase in average peak load at dwell. Enhanced resiliency of the heat treated Rene 41 spring tube was observed at multiple test temperatures, as depicted in figure 17. In contrast to that of the Inconel ST-5, the effect of heat treatment on performance for the Rene samples directly correlated to the expected behavior based on yield strength considerations (i.e., enhanced performance with heat treatment due to increased yield strength though precipitation hardening). Despite the degradation in resiliency of the non heat treated Rene ST-5, its performance was nearly as good as that of the heat treated Inconel samples at all test temperatures (table 4).
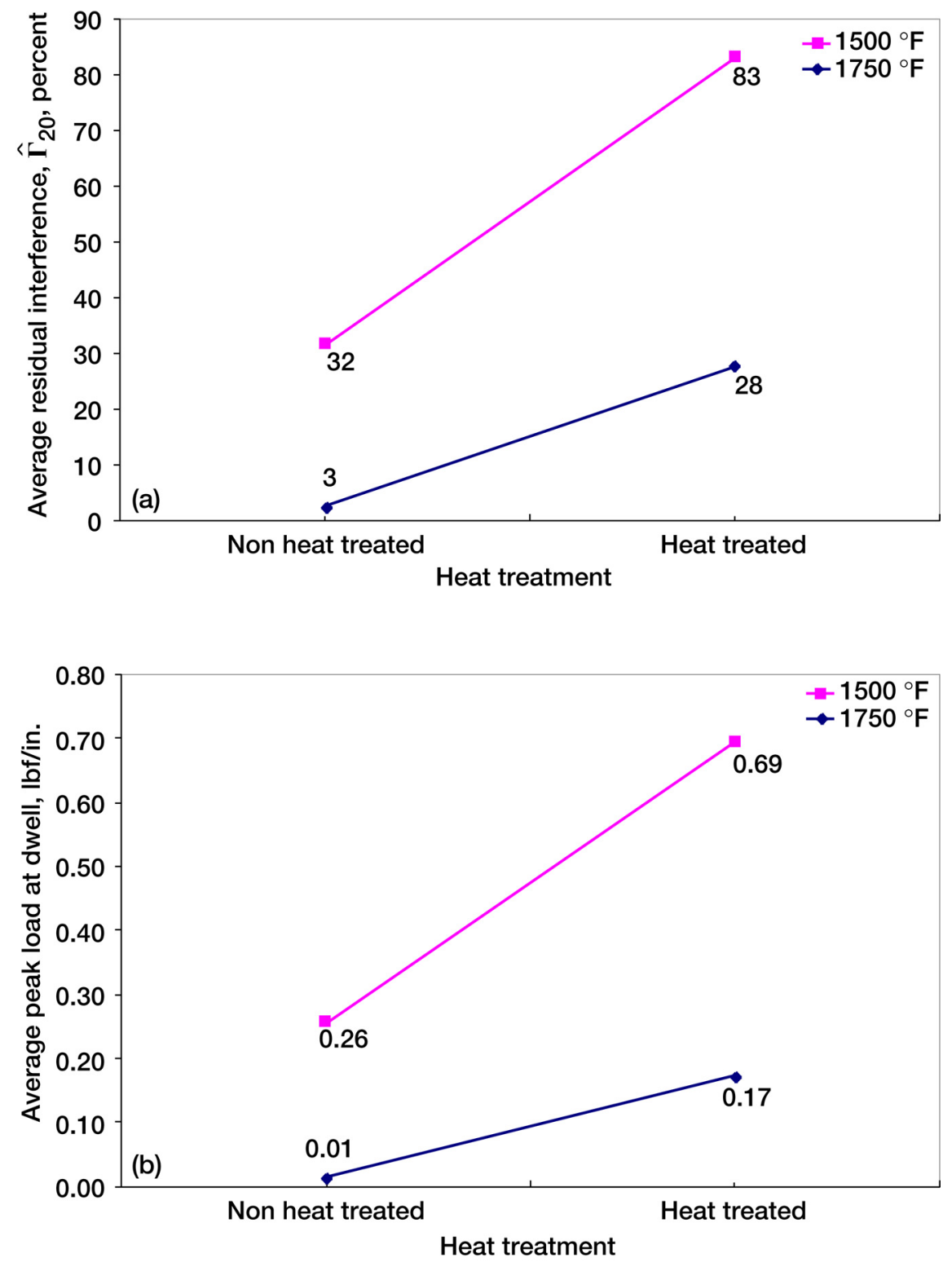

Figure 16.-Effects plots of the impact of heat treatment of the Rene 41 ST-5 on (a) average resiliency, and (b) average peak load, for compression cycle 20 at both $1500^{\circ} \mathrm{F}$ and $1750^{\circ} \mathrm{F}$. 


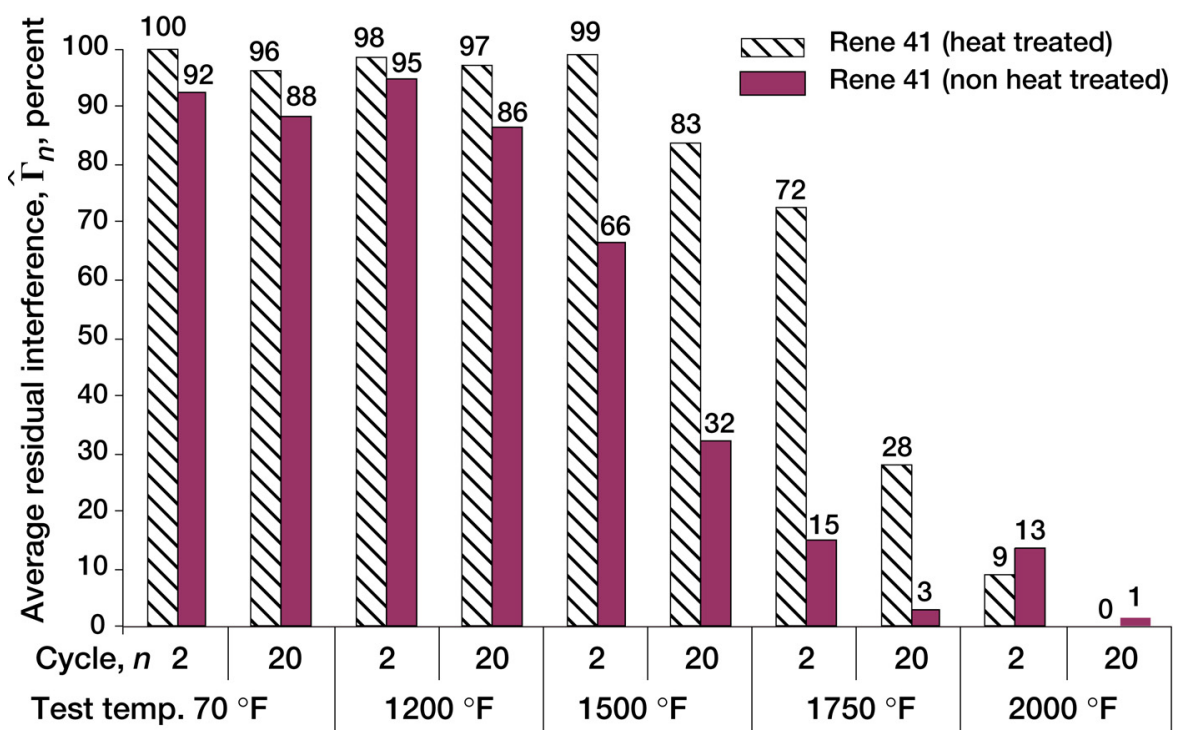

Figure 17.-Comparison of spring tube resiliency at the start of compression cycles 2 and 20 for heat treated and non heat treated Rene 41 using the ST-5 knit geometry at multiple test temperatures.

\section{Summary of Spring Tube Modification Effects on Resiliency}

Figure 18 presents a comparative summary of the effects of the spring tube modifications evaluated in this study, based on average resiliency at the start of cycle 10. All data presented in the graph is from tests conducted at $1500^{\circ} \mathrm{F}$. It is clear from this data that material substitution and heat treatment of the Rene 41 specimens had the greatest impact on spring tube resiliency. At $1500^{\circ} \mathrm{F}$, heat treated ST-5 spring tubes fabricated from Rene 41 alloy showed a $2.5 \mathrm{x}$ resiliency improvement over those constructed from the baseline Inconel X-750 material. Heat treating the Rene 41 ST-5 spring tube improved resiliency by 93 percent when compared to the non heat treated specimen. The other modifications, loop density, number of strands, and heat treatment of the Inconel X-750 specimens, had less significant effects on observed residual interference. Increasing the loop density from 34 to 64 produced a small improvement in resiliency, approximately 21 percent, whereas increasing the number of strands from 1 to 3 caused a negligible decrease in residual interference ( 7 percent). Based on the observed trends, spring tube resiliency could be maximized within the evaluated set of design parameters by fabricating a spring tube with a loop density of 64 from heat treated Rene 41 wire. 


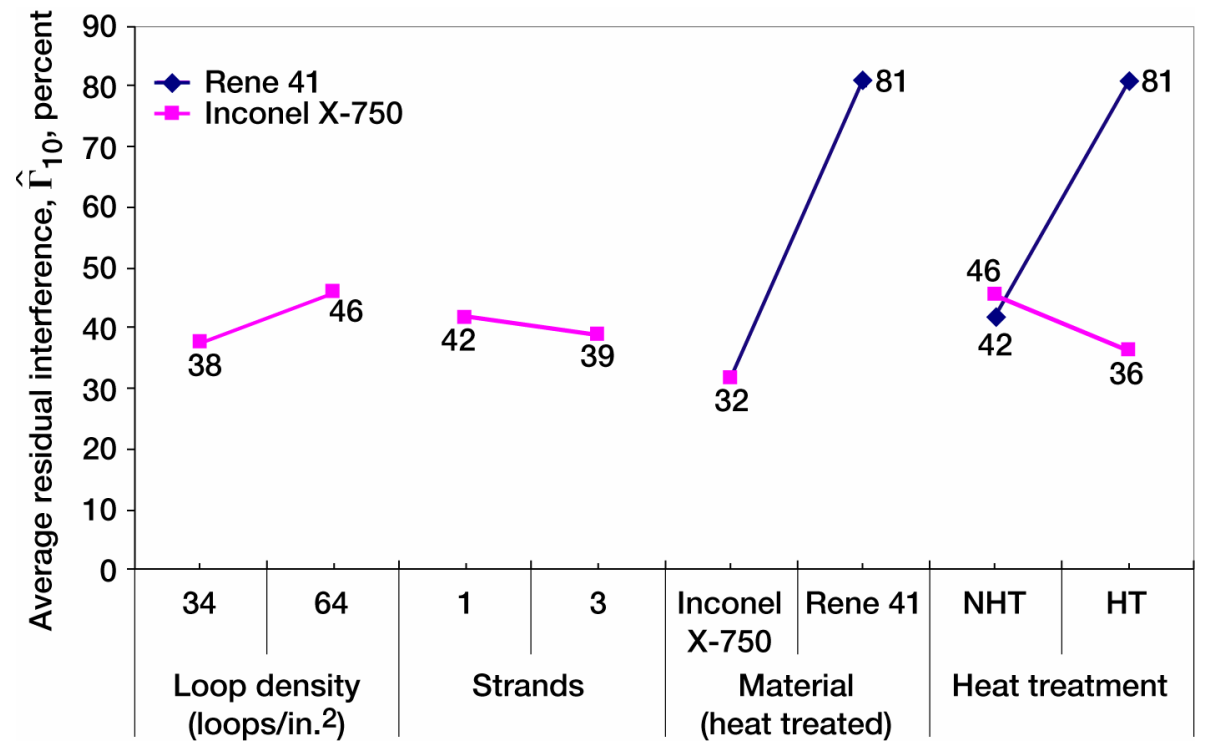

Figure 18.- Summary of geometry and material effects on average spring tube resiliency at $1500{ }^{\circ} \mathrm{F}$ at the start of cycle 10 . Note that the tests used to evaluate the effects of material selection (Inconel X-750 and Rene 41) and heat treatment (Rene 41 only) were conducted using a grooved seal holder. All other tests utilized a flat platen.

\section{Conclusions}

The current baseline control surface seal does not satisfy all of the demanding requirements for use on advanced space vehicles. Limited high temperature resiliency of the seal could permit excessive leakage of hot gases past the seal, exposing underlying temperature sensitive structures. To address this problem, an evaluation of the effects of knit geometry and material modifications on the performance of the spring tube preloading component used in the current seal design was performed. After completing a series of compression tests, the following conclusions were drawn:

1. Of the factors evaluated, material selection showed the most significant impact on spring tube resiliency and load retention. At $1500^{\circ} \mathrm{F}$, the heat treated Rene 41 spring tube demonstrated a $2.5 \mathrm{x}$ resiliency improvement over the baseline Inconel X-750 design at the start of compression cycle 10. This material also produced approximately a $275^{\circ} \mathrm{F}$ improvement in temperature capability (for a residual interference of $\sim 75$ percent) when compared to Inconel X-750, and it exhibited sustained spring tube resiliency to at least $1750^{\circ} \mathrm{F}$. Applied loads produced by Rene 41 spring tubes with the baseline geometry were well below the maximum acceptable loads for control surface structures. Despite significant performance improvements realized using the Rene 41 spring tube, nearly all resiliency was lost in the first few compression cycles at $2000{ }^{\circ} \mathrm{F}$. As a result, alternate materials will be required to reach the highest prescribed application temperature.

2. Heat treatment of the Rene 41 spring tube significantly enhanced resiliency at elevated temperatures. At the start of compression cycle 10 at $1500{ }^{\circ} \mathrm{F}$, heat treatment of the Rene 41 spring tubes showed almost a $2 \mathrm{x}$ increase in resiliency when compared to a non heat treated specimen. Similar improvements were not observed in the Inconel X-750 spring tubes. 
3. The impact of knit geometry modifications on spring tube performance was moderate, with changes to the loop density showing the largest effect. At the start of compression cycle 10 of tests conducted at $1500{ }^{\circ} \mathrm{F}$, a loop density increase from 34 to 64 in single strand Inconel specimens produced an increase in average resiliency of approximately 21 percent, but no substantial increase in load. Increasing the number of strands from 1 to 3 produced a negligible effect on average resiliency but more than doubled peak load. Although the impact of geometry modification on spring tube performance was moderate, observed trends in the collected data suggested that a more structured DOE could be useful in generating spring tubes with enhanced performance capabilities.

\section{References}

1 Dunlap, P.H., Steinetz, B.M. and Curry, D.M., "Rudder/Fin Seal Investigations for the X-38 Re-Entry Vehicle," NASA/TM-2000-210338/REV1, AIAA-2000-3508, November 2000.

2 Dunlap, P.H., Steinetz, B.M., Curry, D.M., Newquist, C.W., and Verzemnieks, J., "Further Investigations of Control Surface Seals for the X-38 Re-Entry Vehicle," NASA/TM-2001-210980.

3 Dunlap, P.H., Steinetz, B.M., Curry, D.M., DeMange, J.J., Rivers, H.K., and Hsu, S.Y., "Investigations of Control Surface Seals for Re-Entry Vehicles," NASA/TM-2002-211708, July 2002.

4 DeMange, J.J., Dunlap, P.H., and Steinetz, B.M., "Advanced Control Surface Seal Development for Future Space Vehicles,” NASA/TM-2004-212898, January 2004.

5 Knitted Wire Spring Specification, Specification Number MB0160-047, Revision D, The Boeing Company, Huntington Beach, Apr. 2001.

6 Stoloff, N. S., "Wrought and P/M Superalloys," ASM Handbooks Online, Volume 1, Properties and Selection: Irons, Steels, and High Performance Alloys, ASM International, 2002.

7 Stoloff, N. S., Simms, C. T., and Hagel, W. C. (eds.), Superalloys II, John Wiley and Sons, Inc., 1987, pp. 575-596.

$8 \quad$ Material Data Sheet ODS_-Superalloy PM 2000, Plansee, May 1992.

$9 \quad$ Klopp, W.D., Aerospace Structural Metals Handbook, Rene 41 (Code 4205), Purdue Research Foundation, West Lafayette, 1994.

10 Dunlap, P.H., Steinetz, B.M., DeMange, J.J., and Taylor, S.C., "Toward an Improved Hypersonic Engine Seal,” NASA/TM-2003-212531, AIAA-2003-4834. 
Public reporting burden for this collection of information is estimated to average 1 hour per response, including the time for reviewing instructions, searching existing data sources, gathering and maintaining the data needed, and completing and reviewing the collection of information. Send comments regarding this burden estimate or any other aspect of this collection of information, including suggestions for reducing this burden, to Washington Headquarters Services, Directorate for Information Operations and Reports, 1215 Jefferson Davis Highway, Suite 1204, Arlington, VA 22202-4302, and to the Office of Management and Budget, Paperwork Reduction Project (0704-0188), Washington, DC 20503.

\begin{tabular}{|l|l|l|}
\hline 1. AGENCY USE ONLY (Leave blank) & $\begin{array}{c}\text { 2. REPORT DATE } \\
\text { September } 2004\end{array}$ & $\begin{array}{r}\text { 3. REPORT TYPE AND DATES COVERED } \\
\text { Technical Memorandum }\end{array}$ \\
\hline
\end{tabular}

\section{TITLE AND SUBTITLE}

5. FUNDING NUMBERS

Evaluation of High Temperature Knitted Spring Tubes for Structural

Seal Applications

\section{AUTHOR(S)}

Shawn C. Taylor, Jeffrey J. DeMange, Patrick H. Dunlap, Jr., and Bruce M. Steinetz

\section{PERFORMING ORGANIZATION NAME(S) AND ADDRESS(ES)}

National Aeronautics and Space Administration

John H. Glenn Research Center at Lewis Field

Cleveland, Ohio 44135-3191

WBS-22-794-40-4V

\section{SPONSORING/MONITORING AGENCY NAME(S) AND ADDRESS(ES)}

National Aeronautics and Space Administration

Washington, DC 20546-0001

8. PERFORMING ORGANIZATION

REPORT NUMBER

E-14679

\section{SUPPLEMENTARY NOTES}

Prepared for the 40th Joint Propulsion Conference and Exhibit cosponsored by AIAA, ASME, SAE, and ASEE, Fort

Lauderdale, Florida, July 11-14, 2004. Shawn C. Taylor, Case Western Reserve University, 10900 Euclid Avenue,

Cleveland, Ohio 44106-4901; Jeffrey J. DeMange, University of Toledo, 2801 W. Bancroft Street, Toledo, Ohio 43606;

Patrick H. Dunlap, Jr., and Bruce M. Steinetz, Glenn Research Center. Responsible person, Shawn C. Taylor,

organization code 5950, 216-433-6374.

12a. DISTRIBUTION/AVAILABILITY STATEMENT

12b. DISTRIBUTION CODE

Unclassified - Unlimited

Subject Category: 37

Distribution: Nonstandard

Available electronically at http://gltrs.grc.nasa.gov

This publication is available from the NASA Center for AeroSpace Information, 301-621-0390.

13. ABSTRACT (Maximum 200 words)

Control surface seals are crucial to current and future space vehicles, as they are used to seal the gaps surrounding body flaps, elevons, and other actuated exterior surfaces. During reentry, leakage of high temperature gases through these gaps could damage underlying lower temperature structures such as rudder drive motors and mechanical actuators, resulting in impaired vehicle control. To be effective, control surface seals must shield lower temperature structures from heat transfer by maintaining sufficient resiliency to remain in contact with opposing sealing surfaces through multiple compression cycles. The current seal exhibits significant loss of resiliency after a few compression cycles at elevated temperatures (i.e., $1900{ }^{\circ} \mathrm{F}$ ) and therefore would be inadequate for advanced space vehicles. This seal utilizes a knitted Inconel X-750 spring tube as its primary resilient element. As part of a larger effort to enhance seal resiliency, researchers at the NASA Glenn Research Center performed high temperature compression testing (up to $2000^{\circ} \mathrm{F}$ ) on candidate spring tube designs employing material substitutions and modified geometries. These tests demonstrated significant improvements in spring tube resiliency $\left(5.5 \mathrm{x}\right.$ better at $\left.1750^{\circ} \mathrm{F}\right)$ through direct substitution of heat treated Rene 41 alloy in the baseline knit design. The impact of geometry modification was minor within the range of parameters tested, however trends did suggest that moderate resiliency improvements could be obtained by optimizing the current spring tube geometry.

14. SUBJECT TERMS

Seals; Resiliency; Design; Test; High temperature 15. NUMBER OF PAGES 26

\begin{tabular}{|c|c|c|}
\hline $\begin{array}{c}\text { 17. SECURITY CLASSIFICATION } \\
\text { OF REPORT }\end{array}$ & $\begin{array}{c}\text { 18. SECURITY CLASSIFICATION } \\
\text { OF THIS PAGE } \\
\text { Unclassified }\end{array}$ & $\begin{array}{c}\text { 19. SECURITY CLASSIFICATION } \\
\text { OF ABSTRACT } \\
\text { Unclassified }\end{array}$ \\
\hline
\end{tabular}



